\title{
Tribulus terrestris Hydroalcoholic Extract Administration Effects on Reproductive Parameters and Serum Level of Glucose in Diabetic Male Rats
}

\author{
Efectos de la Administración del Extracto Hidroalcohólico Tribulus terrestris sobre \\ los Parámetros Reproductivos y el Nivel Sérico de Glucosa en Ratas Macho Diabéticas
}

Ali Ghanbari; Mojtaba Moradi**; Amir Raoofi: $^{* * *}$ Mahsa Falahi $^{* * * * *}$ \& Sepideh Seydi ${ }^{* * * *}$

GHANBARI, A.; MORADI, M.; RAOOFI, A.; FALAHI, M. \& SEYDI, S. Tribulus terrestris hydroalcoholic extract administration effects on reproductive parameters and serum level of glucose in diabetic male rats. Int. J. Morphol.,34(2):796-803, 2016.

SUMMARY: Usage of medicinal plants for the treatment of diseases is a remarkable strategy considered in both clinical and experimental studies. This study was conducted to evaluate the effect of Tribulus terrestris hydroalcoholic extract administration on the serum level of glucose and reproductive parameters in diabetic male rats. In this experimental study, 30 adult male Wistar rats (200-250 g) were divided into 5 groups $(\mathrm{n}=6)$. Diabetes was induced by a single intraperitoneal injection of $50 \mathrm{mg} / \mathrm{kg}$ streptozotocin. Experimental groups received daily Intraperitoneal injection of the extract $(100,250$ and $500 \mathrm{mg} / \mathrm{kg}$ ) since one week after inducing diabetes for two weeks. At the end of the experiment, the serum levels of testosterone and glucose were examined by ELISA and Glucodr devices respectively. Sperm parameters including morphology, count and motility were evaluated from the cauda epididymis. The diameters of seminiferous tubules were assessed based on $5 \mu \mathrm{m}$ paraffin section of H\&E stained section of testes. The data were evaluated by One Way ANOVA followed by post-hoc test using SPSS software. In T. terrestris extract groups, there were significant reductions in the levels of blood glucose while increased sperm motility, sperm count and seminiferous tubules diameter, percentage of sperms with normal morphology, level of testosterone hormone and final body weight compared with diabetic group ( $\mathrm{p}<0.001)$. In conclusion, $T$. terrestris hydroalcoholic extract decreases serum level of glucose and diminishes the side effects of diabetes on male reproductive system showing by increasing in the serum level of testosterone, improving sperm parameters and returning the seminiferous tubules to normal diameter by a dose dependent manner.

KEY WORDS: Diabetes; Glucose; Rat; Streptozotocin; Testosterone; Tribulus terrestris.

\section{INTRODUCTION}

Diabetes mellitus (DM) is one of the most prevalent diseases in developing countries. It has been estimated that by the year 2030, the number of diabetic's patients in the world will reach to 336 million (Wild et al., 2004). Diabetes mellitus is characterized by hyperglycemia, changing in the metabolism of lipids, carbohydrates and proteins that are consequences of reducing cellular secretion of insulin or insulin resistance (Amaral et al., 2008).

Side effects of diabetes can be seen in all body systems. Physical disability, renal impairment, visual impairment, heart disease and sexual dysfunction are the main side effects of diabetes (Engelgau et al., 2004).
On male reproductive system, diabetes mellitus decreases libido and testosterone production, inhibits spermatogenesis, declines in the diameter of seminiferous tubules, and degenerate testicular germ cells (Guneli et al., 2008). There are several techniques to induce experimental diabetes in laboratory animals including chemical destroying beta cell mass and surgical excision of the pancreas. Also the various chemical factors like Streptozotocin can cause diabetics changes (Rasch et al., 1979). Streptozotocin insert its diabetic effects within two or three days by damaging the beta cell's membrane and induction of DNA strand breaks, that causes beta cells death and leads to type I of diabetes in experimental animals (Yamamoto et al., 1981).

\footnotetext{
* Fertility and Infertility Research Center, Kermanshah University of Medical Sciences, Kermanshah, Iran.

** Department of Physiology, Ahvaz Jundishapur University of Medical Sciences, Ahvaz, Iran.

*** Department of Anatomy, Shahid Beheshti University of Medical Sciences, Tehran, Iran.

${ }^{* * * *}$ Student Research Committee, Kermanshah University of Medical Sciences, Kermanshah, Iran. 
Currently, effective therapies for diabetes are using insulin and hypoglycemic drugs, but these compounds also have numerous adverse effects (Suji \& Sivakami, 2003). Another strategy for diabetes treatment is using medicinal plants and their derivatives (Shapiro \& Gong, 2002; Salimi et al., 2015). In this regard, World Health Organization (WHO) has a particular emphasis on the development of herbal antidiabetic drugs (Suji \& Sivakami; Stanley et al., 2000).

Tribulus terrestris is a yearling plant widely distributed in the Mediterranean and the warm parts of Europe, Asia, USA, Africa and Australia (Chen et al., 2013). This plant is used in traditional medicine in China, India, Iraq, Iran, etc. Studies show that T. terrestris contains steroids, saponins, flavonoids, alkaloids, unsaturated fatty acids, vitamins, tannins, resins, potassium, nitrate, aspartic acid and glutamic acid (Yan et al., 1996). This plant has many medical effects including; antimicrobial, antibacterial, anti-oxidant and anti-toxic. The plant is also used for the treatment of cardiovascular diseases, cancers, respiratory diseases and joint pain (Kadry et al., 2010). The use of $T$. terrestris extract increases body's ability to build muscle mass and strength and also improves circulation and oxygen transfer (Arsyad, 1996). Long term use of T. terrestris causes dilatation of the vessels and improves coronary arteries without side effects (Wang et al., 1990). Trybstan is one of the T. terrestris compounds that increases libido and counteract of cold-natured infertility and menopausal disorders. Researchers have shown that $T$. terrestris extract increases sexual potency in men by increasing level of free testosterone and regulating the amount of estrogen, progesterone and pregnenolone (Ghosian Moghaddam et al., 2013). Further, the use of the plant in traditional medicine in India and China is to treat sexual dysfunction and increase libido by increasing the level of testosterone and $\mathrm{LH}$ (Martino-Andrade et al., 2010; Park et al., 2006). However, a study has shown that $T$. terrestris had no effect on the organs such as the prostate, seminal vesicles, uterus and vagina that are sensitive to endocrine system (Martino-Andrade et al.). On the other hand, using $T$. terrestris with other herbs including ginseng, soy and berries improves erectile and sexual behavior in rats (Park et al.). Finally, Saponin derived from $T$. terrestris had a significant effect in reducing serum glucose levels that could introduce the plant as a potent medicinal plant for the treatment of diabetes (Li et al., 2002).

According to the literature, there was no report about the effect of $T$. terrestris extract on reproductive parameters in diabetic subjects. In this regards, present study was conducted to determine the effect the extracts of on glucose and testosterone serum levels, testis tissue, and sperm parameters of STZ induced diabetic rats.

\section{MATERIAL AND METHOD}

Animals. The present study worked on adult male Wistar rats and the mean age of 70 days weighting 200-250 g that were obtained from Pasteur Institute. They were kept in the departmental animal house at temperature $26 \pm 2{ }^{\circ} \mathrm{C}$ and relative humidity $44-56 \%$, light and dark cycles of 10 and $14 \mathrm{~h}$ respectively for one week before and during the experiments. Animals were provided with standard rodent pellet diet and the food was withdrawn 18-24 $\mathrm{h}$ before the experiment though water was allowed ad libitum. All studies were performed in accordance with the guide for the care and use of laboratory animals, as adopted and promulgated by the Animal Care Committee of Kermanshah Medical Sciences University, Iran.

Preparation of extract. The seeds of $T$. terrestris were prepared from a traditional medicine center and were identified and approved by a botanist. Extracting was performed by percolation method as described earlier (Raoofi et al., 2015).

Experimental induction of diabetes in rats. Diabetes was induced by using streptozotocin as diabetogenic agent.streptozotocin (STZ) $(50 \mathrm{mg} / \mathrm{kg})$ produced by the USA Sigma company was dissolved in citrate buffer $(\mathrm{pH} 4.5)$ immediately before use. The solution was injected intraperitoneally in a dose of $50 \mathrm{mg} / \mathrm{kg}$. One week after STZ administration, Blood was taken from the tail of the rats. Then by using Glucodr devices, Super Sensor model, making South Korea, blood glucose samples were measured. Glucose level over $200 \mathrm{mg} / \mathrm{dL}$ was considered diabetic (Lenzen, 2008).

Experimental design. Rats were divided into five groups of six rats in each group.

Group I: Normal control group; the rats were treated with distilled water.

Group II: Diabetic control group; the rats were treated with distilled water.

Group III: Diabetic A group; the rats were treated with 100 $\mathrm{mg} / \mathrm{kg}$ T. terrestris extract.

Group IV: Diabetic B group; the rats were treated with 250 $\mathrm{mg} / \mathrm{kg}$ T. terrestris extract.

Group V: Diabetic C group; the rats were treated with 500 $\mathrm{mg} / \mathrm{kg}$ T. terrestris extract. 
Antidiabetic activity of $T$. terrestris hydroalcoholic extract was evaluated by Glucodr device to estimate blood glucose levels and also by body weight measurement. The extract was dissolved in distilled water and administered (I.P) to rats daily with specified doses for two weeks. At the end of the experiment (day 22), the rats were weighed (secondary weight) and anesthetized $24 \mathrm{~h}$ after the last injection. Blood samples were taken from the heart and its serum was separated by centrifuge.

Analysis of testis weight and testosterone hormone. The animals were anesthetized $24 \mathrm{~h}$ after the last injection. Blood was taken from the heart and preserved at a temperature of $37^{\circ} \mathrm{C}$ for $30 \mathrm{~min}$ and the collected blood was centrifuged at $25^{\circ} \mathrm{C}$ for $10 \mathrm{~min}$ with $4000 \mathrm{rpm}$ to obtain the serum. The serum samples were then kept in deep freezer $\left(-18^{\circ} \mathrm{C}\right)$ until measurement of testosterone hormone by ELISA method. Also, the testes were separated and weighed separately and then preserved in neutral buffered formalin $10 \%$ (Keshtmand et al., 2015; Moradi et al., 2015).

Evaluation of sperm characteristics. Both cauda epididymis from each rat were placed in $2 \mathrm{~mL}$ of normal saline, pre-warmed at $37^{\circ} \mathrm{C}$. Cauda epididymis was separated into small segments and placed in the medium DMEM/F12 containing FBS $5 \%$ which had been previously balanced in the incubator with the temperature of $37{ }^{\circ} \mathrm{C}$ and $\mathrm{CO}_{2} 5 \%$. The prepared suspension was used for the analysis of sperm parameters including: motility, count and morphology. Sperm motility was divided into four levels: (0): without motility, (I): minor in situ motility. (II): circumferential motility and (III): progressive motility (Jequier, 2000).

Morphologic analysis of sperm count and motility. To count the sperms, after putting the sperm suspension on Neubauer's chamber, the sperms on the four corners of the central square were counted. To examine the sperm cells morphology, smear was prepared from the samples and was stained and investigated by Papanicolaou method (Lotfi et al., 2013).
To determine the motility, one drop of the sperm cells suspension was placed on the chamber and the motile and immotile sperm cells were analyzed by microscope with magnification 400X (Keshtmand et al., 2015).

Histological analysis. The testes were preserved in neutral buffered formalin $10 \%$. The paraffin blocks were prepared and were cut in $5 \mu \mathrm{m}$ thick sections, which were stained with hematoxylin and eosin and examined by light microscope at X400 magnifications. Seminiferous tubules diameter was measured by Motic camera and software (AE3; Motic S.L.U., Barcelona, Catalonia, Spain). Briefly, more than 20 sections were prepared from each block. The sections numbered 5, 10, 15, and 20 were selected and photographed separately from two random scopes. The mean of seminiferous tubules diameter ( $\mathrm{mm}$ ) was determined for each testis.

Statistical analysis. The results were presented as Mean \pm SEM (Standard Error of Mean) and data were analyzed by One way ANOVA followed by post-hoc test to determine the statistical significance between different groups using SPSS software (version 20) and p <0.05 was considered as statistically significant.

\section{RESULTS}

Weight of Body and Testis: Streptozotocin induced diabetic rats showed significant reduction in body weight compared to normal control group ( $\mathrm{p}<0.001$ ). The mean of final weight in diabetic extract groups $(100,250 \mathrm{mg} / \mathrm{kg})$ revealed a significant decrease compared to normal control group $(\mathrm{p}$ $<0.001$ ) (Table I). Further, the rats receiving 250 and 500 $\mathrm{mg} / \mathrm{kg}$ doses of $T$. terrestris extract indicated significant increase in body weight compared to diabetic control group $(\mathrm{p}<0.001)$ (Table I). Significant weight testis decrease were seen after STZ administration in diabetic control groups compared to normal control one $(\mathrm{p}<0.05)$ (Table I).

Table I. The effect of different doses of T. terrestris extract on body weight, testis weight and seminiferous tubule diameter in sham and experimental groups. The data are shown as Mean \pm Standard Error of Mean.

\begin{tabular}{lccc}
\hline Groups & Body weight $(\mathbf{g})$ & Testis weight $(\mathbf{g})$ & S. T. D ( m) \\
\hline Normal control & $237.8 \pm 16.1$ & $1.45 \pm 0.1$ & $270 \pm 30.2$ \\
Diabetic & $156.3 \pm 12.2^{*^{*}}$ & $1.2 \pm 0.07^{*}$ & $173 \pm 22.5^{* *}$ \\
Diabetic+ T. terrestris $(100 \mathrm{mg})$ & $177.5 \pm 14.3^{* *}, \#$ & $1.33 \pm 0.3$ & $201 \pm 22.1^{* *}$,\# \\
Diabetic+ T. terrestris $(250 \mathrm{mg})$ & $184.2 \pm 14.8^{* *}, \# \#$ & $1.36 \pm 0.06$ & $204 \pm 20.6^{* *}$, \# \\
Diabetic+ T. terrestris $(500 \mathrm{mg})$ & $217.8 \pm 15.1^{\#}$ & $1.38 \pm 0.05$ & $216 \pm 30.1^{* *}$, \#\# \\
\hline
\end{tabular}

S.T.D $=$ Seminiferous tubule diameter; $* *=p<0.001$, the mean difference is significant compared to Normal control group. \#\#= $\mathrm{p}<0.001$, the mean difference is significant compared to Diabetic group. $\#=p<0.001$, the mean difference is significant compared to Diabetic group. $*=p<0.05$, the mean difference is significant compared to normal control group. 
Blood sugar: The mean of blood glucose in experimental groups was increased significantly compared to normal control group ( $\mathrm{p}<0.001$ ), while blood glucose in diabetic rats receiving the extract $(100,250$ and $500 \mathrm{mg} / \mathrm{kg})$ reduced significantly compared to diabetic group ( $\mathrm{p}<0.001)$ (Table III).

Sperm parameters: The mean of sperm count in diabetic and experimental groups was decreased significantly in comparison with normal control group ( $\mathrm{p}<0.001$ ) (Table II). Analysis of sperm motility indicated that percentage of progressive motile sperms (fast) in diabetic and diabetic+ extract groups decreased significantly compared to normal control group $(\mathrm{p}<0.001)$ (Table II). The percentage of sperms with normal morphology in diabetic and diabetic+ extract groups revealed a significant decrease in comparison with sham group ( $p<0.001)$ (Table II). Sperm abnormal morphology included twisted cauda sperm, round cauda sperm, and headless sperm.

Histological study: The microscopic pictures of testes are shown in Figure 1. The ordered seminiferous tubules and low inter tubular spaces were seen in normal control and somehow in T. terrestris extract treated groups (Fig. 1A, C, $\mathrm{D}$ and $\mathrm{E})$. In diabetic group, the shrinkage of seminiferous tubules as well as high intertubular spaces was seen (Fig

Table II. The effect of different doses of $T$. terrestris extract on sperm motility, sperm count and sperm normal morphology in sham and experimental groups. The data are shown as Mean \pm Standard Error of Mean.

\begin{tabular}{lccc}
\hline Groups & Count (106) & Sperm motility (\%) & Normal morphology (\%) \\
\hline Nomal control & $79.8 \pm 3.2$ & $73.6 \pm 2.2$ & $85.6 \pm 5.8$ \\
Diabetic & $15 \pm 0.5^{* *}$ & $26.8 \pm 1.5^{* *}$ & $55.6 \pm 3.5^{* *}$ \\
Diabetic+ T. terrestris $(100 \mathrm{mg})$ & $38.4 \pm 1.1^{* *}, \# \#$ & $29.5 \pm 0.9^{* *}$ & $58 \pm 2.5^{* *}$ \\
Diabetic+ T. terrestris $(250 \mathrm{mg})$ & $38.9 \pm 1.1^{* *}, \# \#$ & $36.2 \pm 0.9^{* *}, \#$ & $63.2 \pm 2.6^{* *}, \#$ \\
Diabetic+ T. terrestris $(500 \mathrm{mg})$ & $43.6 \pm 2.1^{*}, \#,(@)$ & $40.6 \pm 0.9^{* *}, \#,(@)$ & $65.3 \pm 2.5^{* *}, \#,(a)$ \\
\hline
\end{tabular}

$* *=p<0.001$, the mean difference is significant compared to Normal control group. $\# \#=p<0.001$, the mean difference is significant compared to Diabetic control group. \#= $<<0.05$, the mean difference is significant compared to Diabetic Control group. @= $\mathrm{p}<0.05$, the mean difference is significant compared to Diabetic $+100 \mathrm{mg} / \mathrm{kg}$ T. terrestris extract group.

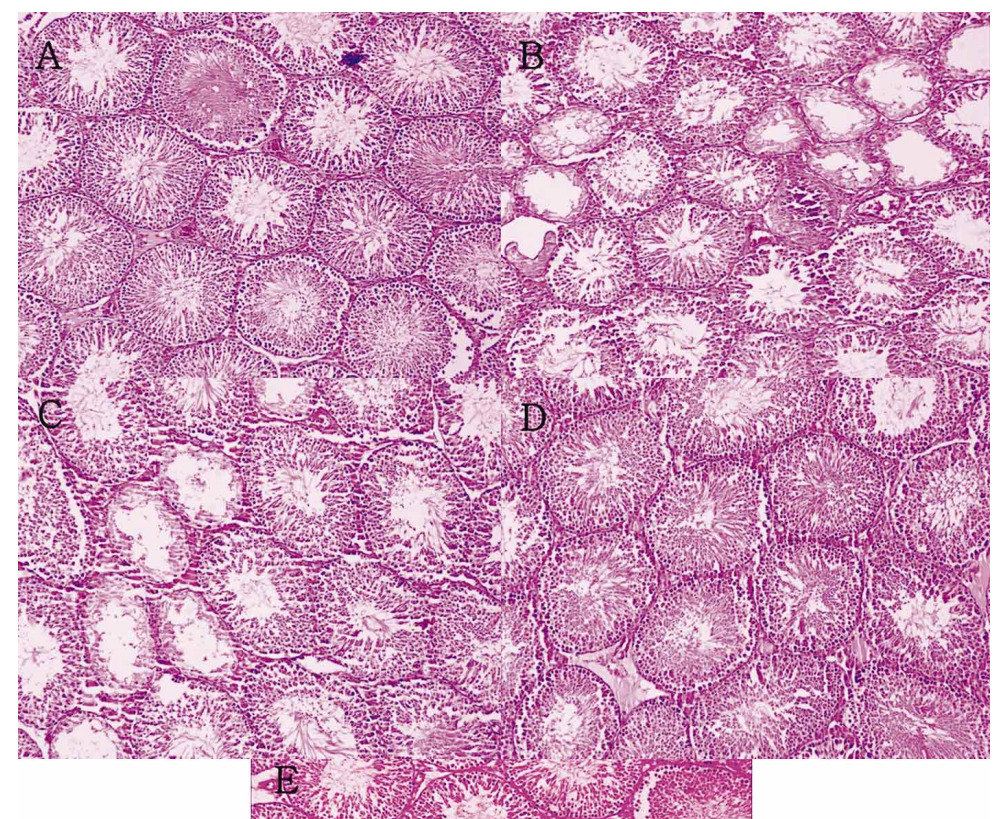

Fig. 1. Seminiferous tubules and calculation of diameter in sham (A), Diabetic Control group (B), $100(\mathrm{C}), 250$ (D), $500(\mathrm{E}) \mathrm{mg} / \mathrm{kg}$ extract $(\mathrm{H} \& \mathrm{E}$, $\mathrm{X} 40)$. 
Table III. The effect of different doses of T. terrestris extract on blood glucose and Testosterone Hormone in different groups. The data are shown as Mean \pm Standard Error of Mean.

\begin{tabular}{|c|c|c|}
\hline Groups & $\begin{array}{l}\text { Blood glucose } \\
\text { (ng/dL) }\end{array}$ & $\begin{array}{c}\text { Testos terone hormone } \\
(\mathrm{ng} / \mathrm{mL})\end{array}$ \\
\hline Normal control & $93.5 \pm 19.3$ & $3.48 \pm 0.6$ \\
\hline Diabetic & $300 \pm 30.4^{\pi *}$ & $2.58 \pm 0.4^{\pi \pi}$ \\
\hline Diabetic $+T$. terrestris $(100 \mathrm{mg})$ & $190 \pm 29.4 *^{*}, \#$ & $2.85 \pm 0.3^{* *}$ \\
\hline Diabetic $+T$. terrestris $(250 \mathrm{mg})$ & $175.3 \pm 26.2^{* *}, \#$ & $3.11 \pm 0.4 \#$ \\
\hline Diabetic $+T$. terrestris $(500 \mathrm{mg})$ & $173.3 \pm 26.8^{\sim \sim, \# \#}$ & $3.16 \pm 0.6^{\# \#}$ \\
\hline
\end{tabular}

$* *=p<0.001$, the mean difference is significant compared to Normal control group. $\# \#=p<0.001$, the mean difference is significant compared to Diabetic Control group. $\#=\mathrm{p}<0.05$, the mean difference is significant compared to Diabetic Control group.

1B). Quantitative analysis of microscopic pictures of testes showed that seminiferous tubules diameter in diabetic rats was significantly reduced in comparison with both normal control and diabetic + extract groups $(\mathrm{p}<0.001)$. When compared to normal control group, a significant boost in seminiferous tubules' diameter was observed in diabetic $+T$. terrestris extract $(500 \mathrm{mg} / \mathrm{kg})(\mathrm{p}<0.001)$ and diabetic $+T$. terrestris extract $(250$ and $100 \mathrm{mg} / \mathrm{kg})(\mathrm{p}<0.05)$ respectively (Table I).

Serum testosterone level: The mean of testosterone level in diabetic control and diabetic $+100 \mathrm{mg} / \mathrm{kg}$ T. terrestris extract groups was decreased significantly in comparison with normal control group ( $\mathrm{p}<0.001)$. Increasing the dose of $T$. terrestris extract showed increased level of testosterone hormone in comparison with diabetic control group (p $<0.001$ ) (Table III).

\section{DISCUSSION}

In the present study, we demonstrated the protective effect of T. terrestris extract on the complication of diabetes such as body weight, blood sugar, testes weight, serum level of testosterone and sperm parameters in the rats.

STZ was used to induce Type1 diabetes and the increased blood glucose was the same as in other studies and that could be contributed to cell death induction of the drug in beta cells of pancreas gland, leading to decrease serum level of insulin (Shenoy \& Ramesh, 2002).

The decreased level of blood sugar in diabetics rats treated with T. terrestris extract was similar to results of ElTantawy \& Hassanin (2007) and could be contributed to antioxidant effect of the extract.

Our study also showed a significant decrease in the weight of diabetic rats compared with normal control group.
These data were similar to other studies (Shenoy \& Ramesh; Suthagar et al., 2009; Kianifard et al., 2011). The weight gain in diabetic rats that were treated with $T$. terrestris confirmed Keshtmand et al. (2015). The study showed that weight loss caused by diabetes can be compensated by $T$. terrestris extract first time. We can conclude that $T$. terrestris extract can be helpful for weight loss in chronic diseases such as diabetes. A significant decrease was observed in testicular weight in diabetic group. These data were in parallel with Cameron et al. (1985), that showed that diabetes had caused tubule atrophy and reduced spermatogenic cells, which could be considered signs of morphological abnormalities in spermatogenesis. We demonstrated that testicular weight was increased in the diabetic $+T$. terrestris treated rats. Thus, it can be concluded that $T$. terrestris extract has had a positive effect on testis weight. The reduction of seminiferous tubule diameter in diabetic rats confirms the hazardous effect of diabetes in testis tissue. Further, the recovery of $T$. terrestris extract in this issue showed in beneficial effect of the extract both in histological and gross levels. The beneficial effect of $T$. terrestris on testis tissue is in parallel with previous studies (Suthagar et al.; Kianifard et al.).

Moreover, studies suggested that diabetes causes reducing testicular weight by launching of the mechanism of cell death. Atrophy of tubules will be followed by reducing the diameter of the tubules and loss of spermatogenic cell (Guneli et al.). Thus, in the diabetic rats that were treated by T. terrestris extract, it can be said that increase in testicular weight may be due to inhibition of apoptosis in spermatogenic cells and this cellular process affects sperm production by increasing sperm parameters.

The present study confirmed other studies and offered that diabetes decreases secretion of androgens. This side effect of diabetes can be due to interference with performance of interstitial endocrine cells (Leydig cells) (Ferlin et al., 2008; Feng et al., 1999). Maneesh et al. (2006) and Stanciu et al. (2010), showed that diabetes affected 
Hypothalamus-Pituitary-gonadal axis in males and decreased testosterone significantly.

On the other hand, improving sperm parameters in T. terrestris treated rats could be due to increasing testosterone. Xu et al. (2001), have shown that T. terrestris was able to improve sexual function, including an increase in sperm count, improving erectile function and increasing libido, and it could be the effect of saponin compound of $T$. terrestris on testosterone production. Brown et al. (2001) and his colleagues have indicated that Frostanole, one of $T$. terrestris saponins, stimulated spermatogenesis by increasing production of pituitary gonadotropins that triggered testosterone and improved sperm count. Various steroids of T. terrestris stimulate spermatogenesis and increase sperm production by affecting sustentocytes (Sertoli cells) (Adimoelja \& Adaikan, 1997). Natural glycosides of $T$. terrestris may have an intermediary and facilitating role in androgen production from estradiol (Ebisch et al., 2007).

Diabetes has general effects on whole body by reducing body weight. This disease also causes degradation of spermatogenesis. Diabetes affects spermatogenesis by reducing the number and function of interstitial endocrine cell and sustertocytes that could be seen by decreasing the seminiferous tubules' diameter, decreasing in the amount of testosterone, and diminishing in the sperm parameters. $T$. terrestris extract as a public body booster, compensates weight loss caused by diabetes. Considering the involvement of oxidative stress both in damaging of the tissues and diabetes, and antioxidant activity of the extract, it could be said that scavenging oxidative compounds is a cause for the beneficial effect of $T$. terrestris extract on complications of diabetes on male reproductive system as well as whole body systems and decreasing the amount of blood glucose of diabetic rats. A specified therapeutic pathway of T. terrestris extract administration on the male reproductive system could be explained by the presence of steroids compounds of the extract that increases the serum level of testosterone.

\section{ACKNOWLEDGMENTS}

The paper is supported by a grant (no. 92185) at Kermanshah University of Medical Sciences.

GHANBARI, A.; MORADI, M.; RAOOFI, A.; FALAHI, M. \& SEYDI, S. Efectos de la administración del extracto hidroalcohólico de Tribulus terrestris sobre los parametros reproductivos y el nivel sérico de glucosa en ratas macho diabéticas. Int. J. Morphol., 34(2):796803, 2016.

RESUMEN: El uso de plantas medicinales para el tratamiento de enfermedades es una importante estrategia considerada en estudios clínicos y experimentales. El objetivo fue evaluar el efecto de la administración de extracto de Tribulus terrestris hidroalcohólico en el nivel sérico de glucosa y los parámetros reproductivos en ratas macho diabéticas. En este estudio experimental, se dividieron 30 ratas Wistar (200-250 g) macho adultas, en 5 grupos $(n=6)$. Se indujo diabetes por una sola inyección intraperitoneal (i.p.) de $50 \mathrm{mg} / \mathrm{kg}$ de estreptozotocina. Los grupos experimentales recibieron inyección i.p diaria del extracto (100, 250 y $500 \mathrm{mg} / \mathrm{kg}$ ) una semana después de la inducción de la diabetes durante dos semanas. Al final del experimento, los niveles séricos de testosterona y de glucosa se examinaron por ELISA y el dispositivos Glucodr, respectivamente. Además, fueron evaluados los parámetros de morfología, conteo y motilidad espermática. Los diámetros de los túbulos seminíferos de los testículos se evaluaron sobre la base de secciones de parafina de $5 \mu \mathrm{m}$ teñidos con H\&E. Los datos fueron evaluados por ANOVA de una vía seguido de prueba post-hoc utilizando el programa SPSS (versión 20). En los grupos tratados con extracto de $T$. terrestris hubo una reducción significativa en los niveles de glucosa en la sangre, mientras que se observó un aumento en el recuento y motilidad espermática, el diámetro de los túbulos seminíferos, el porcentaje de espermatozoides con morfología normal, el nivel de testosterona y el peso corporal final de las ratas en comparación con el grupo de ratas diabéticas (p $<0,001)$. En conclusión, el extracto de T. terrestris hidroalcohólico disminuye los niveles séricos de glucosa y los efectos secundarios de la diabetes en el sistema reproductivo mediante el aumento de los niveles séricos de testosterona, mejorando los parámetros de los espermatozoides y la restitución a diámetro normal de los túbulos seminíferos dependiendo de la dosis.

PALABRAS CLAVE: Diabetes; Glucosa; Rata; Estreptozotocina; Testosterona; Tribulus terrestris .

\section{REFERENCES}

Adimoelja, A. \& Adaikan, P. G. Protodioscin from herbal plant Tribulus terrestris L improves the male sexual functions, probably via DHEA. Int. J. Impot. Res., 9(Suppl. 1):S64, 1997.
Amaral, S.; Oliveira, P. J. \& Ramalho-Santos, J. Diabetes and the impairment of reproductive function: possible role of mitochondria and reactive oxygen species. Curr. Diabetes Rev., 4(1):46-54, 2008. 
Arsyad, K. M. Effect of protodioscin on the quantity and quality of spermatozoon from males with moderate idiopathic oligozoospermia. Medika, 22(8):614-8, 1996.

Brown, G. A.; Vukovich, M. D.; Martini, E. R.; Kohut, M. L.; Franke, W. D.; Jackson, D. A. \& King, D. S. Endocrine and lipid responses to chronic androstenediol-herbal supplementation in 30 to 58 year old men. J. Am. Coll. Nutr., 20(5):520-8, 2001.

Cameron, D. F.; Murray, F. T. \& Drylie, D. D. Interstitial compartment pathology and spermatogenic disruption in testes from impotent diabetic men. Anat. Rec., 213(1):53-62, 1985.

Chen, G.; Su, L.; Feng, S. G.; Lu, X.; Wang, H. \& Pei, Y. H. Furostanol saponins from the fruits of Tribulus terrestris. Nat. Prod. Res., 27(13):1186-90, 2013.

Ebisch, I. M.; Thomas, C. M.; Peters, W. H.; Braat, D. D. \& Steegers-Theunissen, R. P. The importance of folate, zinc and antioxidants in the pathogenesis and prevention of subfertility. Hum. Reprod. Update, 13(2):163-74, 2007.

El-Tantawy, W. H. \& Hassanin, L. A. Hypoglycemic and hypolipidemic effects of alcoholic extract of Tribulus alatus in streptozotocin-induced diabetic rats: a comparative study with T. terrestris (Caltrop). Indian J. Exp. Biol., 45(9):785-90, 2007.

Engelgau, M. M.; Geiss, L. S.; Saaddine, J. B.; Boyle, J. P.; Benjamin, S. M.; Gregg, E. W.; Tierney, E. F.; Rios-Burrows, N.; Mokdad, A. H.; Ford, E. S.; Imperatore, G. \& Narayan, K. M. The evolving diabetes burden in the United States. Ann. Intern. Med., 140(11):945-50, 2004.

Feng, H. L.; Sandlow, J. I.; Sparks, A. E.; Sandra, A. \& Zheng, L. J. Decreased expression of the c-kit receptor is associated with increased apoptosis in subfertile human testes. Fertil. Steril., 7(1):85-9, 1999.

Ferlin, A.; Pengo, M.; Selice, R.; Salmaso, L.; Garolla, A. \& Foresta, C. Analysis of single nucleotide polymorphisms of FSH receptor gene suggests association with testicular cancer susceptibility. Endocr. Relat. Cancer, 15(2):429-37, 2008.

Ghosian Moghaddam, M. H.; Khalili, M.; Maleki, M. \& Ahmad Abadi, M. E. The Effect of Oral Feeding of Tribulus terrestris L. on Sex Hormone and Gonadotropin Levels in Addicted Male Rats. Int. J. Fertil. Steril., 7(1):57-62, 2013

Guneli, E.; Tugyan, K.; Ozturk, H.; Gumustekin, M.; Cilaker, S. \& Uysal, N. Effect of melatonin on testicular damage in streptozotocin-induced diabetes rats. Eur. Surg. Res., 40(4):354-60, 2008.

Jequier, A. M. Male Infertility: A Guide for the Clinician. Bodmin, Wiley-Blackwell Science, 2000.
Kadry, H.; Abou Basha, L.; El Gindi, O. \& Temraz, A. Antioxidant activity of aerial parts of Tribulus alatus in rats. Pak. J. Pharm. Sci., 23(1):59-62, 2010.

Keshtmand, Z.; Ghanbari, A.; Khazaei, M. \& Rabzia, A. Protective effect of Tribulus terrestris hydroalcoholic extract against cisplatin-induced apoptosis on testis in mice. Int. J. Morphol., 33(1):279-84, 2015.

Kianifard, D.; Sadrkhanlou, R. A. \& Hasanzadeh, S. The histological, histomorphometrical and histochemical changes of testicular tissue in the metformin treated and untreated streptozotocin-induced adult diabetic rats. Vet. Res. Forum, 2(1):13-24, 2011.

Lenzen, S. The mechanisms of alloxan- and streptozotocin-induced diabetes. Diabetologia, 51(2):216-26, 2008.

Li, M.; Qu, W.; Wang, Y.; Wan, H. \& Tian, C. Hypoglycemic effect of saponin from Tribulus terrestris. Zhong Yao Cai, 25(6):420$2,2002$.

Lotfi, N.; Khazaei, M.; Shariatzadeh, S. M. A.; Soleimani Mehranjani, S. \& Ghanbari, A. The effect of Cannabis sativa hydroalcoholic extract on sperm parameters and testis histology in rats. Int. J. Morphol., 31(1):82-6, 2013.

Martino-Andrade, A. J.; Morais, R. N.; Spercoski, K. M.; Rossi, S. C.; Vechi, M. F.; Golin, M.; Lombardi, N. F.; Greca, C. S. \& Dalsenter, P. R. Effects of Tribulus terrestris on endocrine sensitive organs in male and female Wistar rats. $J$. Ethnopharmacol., 127(1):165-70, 2010.

Maneesh, M.; Jayalakshmi, H.; Singh, T. A. \& Chakrabarti, A. Impaired hypothalamic-pituitary-gonadal axis function in men with diabetes mellitus. Indian J. Clin. Biochem., 21(1):165-8, 2006.

Moradi, M.; Mahmoodi, M.; Raoofi, A. \& Ghanbari, A. Chorionic morphine, naltrexone and pentoxifylline effect on hypophysogonadal hormones of male rats. Bratisl. Lek. Listy, 116 (4):2769, 2015.

Park, S. W.; Lee, C. H.; Shin, D. H.; Bang, N. S. \& Lee, S. M. Effect of SA1, a herbal formulation, on sexual behavior and penile erection. Biol. Pharm. Bull., 29(7):1383-6, 2006.

Rasch, R. Prevention of diabetic glomerulopathy in streptozotocin diabetic rats by insulin treatment. Kidney size and glomerular volume. Diabetologia, 16(2):125-8, 1979.

Raoofi, A.; Khazaei, M. \& Ghanbari, A. Protective effect of hydroalcoholic extract of Tribulus terrestris on Cisplatin induced renal tissue damage in male mice. Int. J. Prev. Med., 6:11, 2015.

Suji, G. \& Sivakami, S. Approaches to the treatement of diabetes mellitus: an overview. Cell. Mol. Biol. (Noisy-le-grand), 49(4):635-9, 2003. 
Salimi, Z.; Eskandary, A.; Headari, R.; Nejati, V.; Moradi, M. \& Kalhori, Z. Antioxidant effect of aqueous extract of sumac (Rhus coriaria L.) in the alloxan-induced diabetic rats. Indian J. Physiol. Pharmacol., 59(1):87-93, 2015.

Shapiro, K. \& Gong, W. C. Natural products used for diabetes. $J$. Am. Pharm. Assoc. (Wash.), 42(2):217-26, 2002.

Shenoy, A. G. \& Ramesh, K. G. Improvement of insulin sensitivity by perindopril in spontaneously hypertensive and streptozotocin induced diabetic rats. Indian J. Pharmacol., 34:156-64, 2002.

Suthagar, E.; Soudamani, S.; Yuvaraj, S.; Ismail Khan, A.; Aruldhas, M. M. \& Balasubramanian, K. Effects of streptozotocin (STZ)induced diabetes and insulin replacement on rat ventral prostate. Biomed. Pharmacother., 63(1):43-50, 2009.

Stanley, P.; Prince, M. \& Menon, V. P. Hypoglycaemic and other related actions of Tinospora cordifolia roots in alloxan-induced diabetic rats. J. Ethnopharmacol., 70(1):9-15, 2000.

Stanciu, I.; Abboud, A.; Kellman, W.; Williams, D.; Azad, N. Correlation of aging and body mass index with the hypothalamicpituitary-gonadal axis hormones in men, with diabetes mellitus. Open Androl. Journal, 2:6-10, 2010.

Wang, B.; Ma, L. \& Liu, T. 406 cases of angina pectoris in coronary heart disease treated with saponin of Tribulus terrestris. Zhong Xi Yi Jie He Za Zhi, 10(2):85-7, 68, 1990.

Wild, S.; Roglic, G.; Green, A.; Sicree, R. \& King, H. Global prevalence of diabetes: estimates for the year 2000 and projections for 2030. Diabetes Care, 27(5):1047-53, 2004.

Xu, Y. J.; Xie, S. X.; Zhao, H. F.; Han, D.; Xu, T. H. \& Xu, D. M. Studies on the chemical constituents from Tribulus terrestris. Yао Хие Хие Bao, 36(10):750-3, 2001.

Yamamoto, H.; Uchigata, Y. \& Okamoto, H. Streptozotocin and alloxan induce DNA strand breaks and poly(ADP-ribose) synthetase in pancreatic islets. Nature, 294(5838):284-6, 1981.

Yan, W.; Ohtani, K.; Kasai, R. \& Yamasaki, K. Steroidal saponins from fruits of Tribulus terrestris. Phytochemistry 42(5):1417$22,1996$.

\author{
Correspondence to: \\ Mojtaba Moradi \& Amir Raoofi \\ Department of Physiology \\ Ahvaz Jundishapur University of Medical Sciences \\ Ahvaz, IRAN and \\ Department of Anatomy \\ Shahid Beheshti University of Medical Sciences \\ Tehran \\ IRAN
Email: mojtabamoradi20@gmail.com amirrezaraoofi@yahoo.com

Received: 29-10-2015

Accepted: 08-03-2016 